\author{
한우 도체 육질등급 요인 분석과 육질등급에 따른 이화학 및 \\ 관능 특성 \\ 이종문* · 박범영* · 조수현* · 김진형* · 유영모* · 채현석* · 최양일** \\ 농촌진흥청 축산연구소*, 충북대학교**
}

\title{
Analysis of Carcass Quality Grade Components and Chemico- Physical and Sensory Traits of M. longissimus dorsi in Hanwoo
}

J .M. Lee*, B. Y. Park*, S. H. Cho*, J. H. Kim*, Y. M. Yoo*, H. S. Chae* and Y. I. Choi**

National Livestock Research Institute*, Choogbuk National University**

\begin{abstract}
The current study was conducted to analysis the effects of sex and live weight on carcass characteristics using total 773 Hanwoo, and to assess the effects of quality grade on chemico-physical and sensory characteristics in longissimus muscle. Results show that both steer and cow received superior quality grade to bull within the same weight class $(\mathrm{P}<0.05)$. Marbling score, texture, maturity, meat color and fat color were significantly $(\mathrm{P}<0.01)$ affected by sex, whilst only marbling score and maturity were significantly affected by live weight. The ultimate quality grade showed significant relationships with marbling score $\left(\mathrm{r}=-0.81^{* *}\right)$, meat color $\left(\mathrm{r}=0.21^{* *}\right)$, fat color $\left(\mathrm{r}=0.10^{* *}\right)$, and with texture $\left(\mathrm{r}=0.41^{* *}\right)$, but that had no such a relationship with maturity. WB-shear force and cooking loss were decreased when carcass grade was increased $(\mathrm{P}<0.01)$, but water-holding capacity was identical between the quality grades. Objective meat color dimensions in lightness, redness and yellowness were increased for higher quality grade $(\mathrm{P}<0.01)$. Meat flavor, juiciness and tenderness received higher scores for higher quality grade $(\mathrm{P}<0.01)$. Intramuscular fat content had significantly relationships with WB-shear force $\left(r=0.56^{*}\right)$, water-holding capacity $\left(r=0.18^{* *}\right)$, juiciness $\left(r=0.46^{* *}\right)$, tenderness $\left(r=0.49^{* *}\right)$, and flavor intensity $\left(r=0.34^{*}\right)$. In addition, a higher WB-shear force was related to a lower flavor, tenderness and juiciness scores.
\end{abstract}

(Key words : Quality grade, Marbling, Palatability, Hanwoo)

$$
\text { I 서 론 }
$$

우리나라 쇠고기 육질등급은 1992년도에 수 소의 도체 품질위주로 처음 설정되었으나 그 후 거세우와 암소 비육 및 출하체중 증가 등으 로 1998년에 근내지방 부도 위주로 현행 4개 등급으로 개정되었다.

쇠고기의 육질등급 평가요인 및 평가방법은 국가별로 다소 다르나 Donald와 Merkel(1993)은 미국 쇠고기 육질등급의 주요 판정요인은 소비
자가 섭취 시 느끼는 연도, 다즙성, 향미와 같 은 맛과 관련이 높은 근내지방도와 성숙도가 중요한 요인이라고 하였다. 근내지방도는 도 체지방 및 쇠고기 내 지방함량과 상관관계가 높고(Corah 등, 1995), 연도와 관련이 있는 성숙 도는 사육방법과 비육기간 및 연령이 주요 변 이요인으로 구명되어 왔다(Barker 등, 1995).

한우의 육질등급에 대하여 Park 등(2002)은 출하체중의 증가에 따라 높아지고, 성별로는 거세한우가 한우암소 및 수소에 비하여 육질등

Corresponding author : Jong-Moon Lee, National Livestock Research Institute, RDA, \#564 Omochun-dong, Kwonsun-gu, Suwon, Korea, 441-350, Tel: 82-31-290-1688, E-mail : jm9758@rda.go.kr 
급이 우수하였으며 그 원인은 근내지방도 차이 라고 하였고, Kim과 Lee(2003)는 한우고기 1등 급육은 관능특성 중 연도 및 향미보다는 다즙 성에 크게 영향을 준다고 하였다.

쇠고기의 화학적 특성과 관능특성 연구에 있 어서, Lorenzen 등(2003)은 미국의 소비자 만족 도 조사에서 육질등급이 low select 에서 top choice 으로 높아질수록 다즙성과 향미가 우수 한 것으로 보고하였고, Jeremiah 등(2003)은 근 내지방 함량과 수분은 다즙성 변이의 각각 $38.4 \%$ 및 23.0\%를 나타내고, Thompson(2001)은 근내지방 함량이 쇠고기 연도 변이의 $12 \sim 14 \%$ 를 나타낸다고 하였으며, Dikeman(1987)은 소비 자 관능특성과 관련하여 배최장근의 지방함량 은 $3 \%$ 이상 되어야 한다고 제시하였다.

쇠고기의 전단력에 관한 연구에서 Park 등 (2002)은 근내지방 함량이 높을수록 낮은 것으 로 보고하였으며, May 등(1992)은 전단력이 높 을수록 관능특성인 다즙성, 향미 및 연도가 나 쁘다고 하였으며, 관능특성 중 연도는 근내지 방도 $(\mathrm{r}=0.19)$ 보다는 다즙성 $\left(\mathrm{r}=0.73^{* *}\right)$ 에 크게 영향을 받는다고 하였고 Miller 등(2001)은 전단 력에 대한 소비자 평가 연구에서 3.0 이하는 연 하고 5.7이상은 질긴 것으로 평가하였다. 육색 에 대해서 Serra 등(2004)은 근내지방 함량과 $\mathrm{L}^{*}, \mathrm{a}^{*}, \mathrm{~b}^{*}$ 값은 각각 $0.04,0.23$ 및 0.05 의 상관 관계가 있다고 하였다. 따라서 본 연구는 한우 의 도체품질과 육질개선을 위하여 성별, 출하 체중별로 육질등급 평가요인을 분석하고, 육질 등급에 따른 이화학특성 및 관능특성 자료를 제시하는데 그 목적을 두고 수행하였다.

\section{재료 및 방법}

\section{1. 공시재료}

축산연구소에서 1995년부터 2004년 4월까지 축산연구소 부설 도축장에서 도축된 한우 총 773두를 공시하였다. 공시축의 사양관리는 전 체 조사두수 중 전국 80농가에서 구입한 240두 는 농가 사양관리 기준에 준하여 실시되었으 며, 그 외 공시축은 축산연구소의 후대검정사
업과 각종 고급육 생산시험사업의 사양관리 프 로그램에 의해 사육되었다.

도체등급 요인분석은 도축 후 냉각실에서 18 20시간 예냉 된 도체의 13 번째 갈비부위 절개 면에서 축산물 등급 판정사에 의하여 조 사하였으며, 한우등심의 이화학특성 및 관능특 성을 조사하기 위하여 567 두의 배최장근 $2.5 \mathrm{~kg}$ 를 채취하여 Table 4 및 5와 같이 조사항목별 로 분석하였다.

\section{2. 육질 분석}

조단백질, 조지방, 수분 및 회분은 $\mathrm{AOAC}$ (1995) 방법에 준하여 분석하였으며 보수력은 여지 압착법(Ryoichi 등, 1993)을 이용하여 플렉 시 유리판에 시료 $0.5 \mathrm{~g}$ 을 놓은 다음 $35 \sim 50$ $\mathrm{kg} / \mathrm{cm}^{2}$ 의 압력으로 2분간 압착하고, 여과지상의 면적은 planimeter(Constant, 19510)로 측정하여 고기면적과 수분면적비로 보수력을 환산하였 다.

가열감량은 배최장근을 $3 \mathrm{~cm}$ 두께의 스테이 크 모양으로 절단하여 육 내부온도 $70^{\circ} \mathrm{C}$ 에서 10 분간 가열한 후, 가열전후의 중량 차로 계산 하였다.

전단력은 배최장근을 $3 \mathrm{~cm}$ 두께의 스테이크 모양으로 절단하여 육 내부온도 $70{ }^{\circ} \mathrm{C}$ 에서 10 분간 가열한 후 직경 $1.27 \mathrm{~cm}$ 의 코아로 근섬유 방향으로 시료를 채취한 다음 전단력 측정기 (Warner-Bratzler shear force meter, G-R Elec. Mfg. Co., USA)로 측정하였다.

육색측정은 도축 후 24시간 동안 냉각한 냉도체의 13 번째 갈비부위를 절개한 후 30 분 간 발색시킨 다음 Chroma meter(Minolta Co. $\mathrm{CR}$ 301., Japan)를 이용하여 $\mathrm{L}^{*}, \mathrm{a}^{*}, \mathrm{~b}^{*}$ 값을 $\mathrm{ClE}$ (Commision Internationale de Leclairage) 기 준으로 측정하였다. 이때 표준판은 $\mathrm{Y}=92.40$, $\mathrm{x}=0.3136, \mathrm{y}=0.3196$ 의 백색 타일을 사용하 였다.

관능특성은 관능검사요원 15 명중 10 명을 무작위로 차출하여 연도, 향미 및 다즙성을 조사 하였으며, 기호도는 6점 만점제로 측정 하였다. 
3. 통계분석

통계분석은 SAS(1996)를 이용하여 GLM, Duncan-test, correlation coefficients를 분석하였다. 한우의 육질등급 판정요인에 대한 성별 및 출하 체중의 효과를 구명하기 위하여 다음과 같은 선 형모형에 근거하여 분산 분석을 실시하였다.

$$
\begin{aligned}
\mathrm{Y}_{\mathrm{ijk}}= & \mu+\text { SEX }_{\mathrm{i}}+\text { WTCLASS }_{\mathrm{j}}+ \\
& \left(\mathrm{SEX} \times{\text { WTCLASS })_{\mathrm{ij}}+\mathrm{e}_{\mathrm{ijk}}}^{\text {WTCL }}\right.
\end{aligned}
$$

이 식에서

$$
\begin{aligned}
& \mathrm{Y}_{\mathrm{ijk}}=\text { 도체평가형질 } \\
& \mu \quad=\text { 전체평균 } \\
& \mathrm{SEX} \\
& \mathrm{i} \text { 번째 성의 효과 }(\mathrm{i}=1,2,3) ;
\end{aligned}
$$

WTCLASS $_{\mathrm{j}}=\mathrm{j}$ 번째 체중그룹의 효과 $(\mathrm{j}=1,2$,

$$
3,4,5,6) ;
$$

$(\mathrm{SEX} \times \mathrm{WTCLASS})_{\mathrm{ij}}=\mathrm{i}$ 번째 성과 $\mathrm{j}$ 번째 체중그 룹간의 상호작용

$\mathrm{e}_{\mathrm{ijk}}=$ 임의오차이다.

\section{III 결과 및 고찰}

\section{1. 성 및 체중별 육질등급 요인특성}

\begin{tabular}{|c|c|c|c|c|c|c|c|c|c|}
\hline \multirow{2}{*}{ Traits } & \multirow{2}{*}{ Sex } & \multicolumn{6}{|c|}{ Market weight (kg) } & \multirow{2}{*}{ pooled SE } & \multirow{2}{*}{$\mathrm{P} \leqq$} \\
\hline & & $\leq 425$ & $\leq 475$ & $\leq 525$ & $\leq 575$ & $\leq 625$ & $\leq 626$ & & \\
\hline \multicolumn{2}{|c|}{ (No. of herd) } & 38 & 75 & 133 & 163 & 166 & 198 & - & - \\
\hline \multirow{4}{*}{$\begin{array}{l}\text { Marbling } \\
\text { score }\end{array}$} & Cow & $3.07^{\mathrm{a}}$ & $3.29^{\mathrm{a}}$ & $3.70^{\mathrm{a}}$ & $4.00^{\mathrm{a}}$ & - & - & 0.15 & 0.1883 \\
\hline & Bull & $1.00^{\mathrm{b}}$ & $1.32^{\mathrm{b}}$ & $1.34^{\mathrm{b}}$ & $1.61^{\mathrm{b}}$ & $1.83^{\mathrm{b}}$ & $1.96^{\mathrm{b}}$ & 0.06 & 0.0053 \\
\hline & Steer & $2.75^{\mathrm{a}}$ & $2.84^{\mathrm{a}}$ & $3.26^{\mathrm{a}}$ & $3.33^{\mathrm{a}}$ & $3.42^{\mathrm{a}}$ & $4.22^{\mathrm{a}}$ & 0.08 & 0.0006 \\
\hline & pooled SE & 0.26 & 0.18 & 0.14 & 0.13 & 0.13 & 0.12 & - & - \\
\hline \multirow{4}{*}{ Maturity } & Cow & $1.89^{\mathrm{a}}$ & $1.96^{\mathrm{a}}$ & $2.00^{\mathrm{a}}$ & $2.00^{\mathrm{a}}$ & - & - & 0.09 & 0.9658 \\
\hline & Bull & $1.00^{\mathrm{b}}$ & $1.05^{\mathrm{b}}$ & $1.10^{\mathrm{b}}$ & $1.27^{\mathrm{b}}$ & $1.62^{\mathrm{a}}$ & $2.02^{\mathrm{a}}$ & 0.04 & 0.0001 \\
\hline & Steer & $1.25^{\mathrm{ab}}$ & $1.31^{\mathrm{b}}$ & $1.26^{\mathrm{b}}$ & $1.53^{\mathrm{b}}$ & $1.56^{\mathrm{a}}$ & $1.67^{\mathrm{b}}$ & 0.03 & 0.0001 \\
\hline & pooled SE & 0.13 & 0.07 & 0.05 & 0.04 & 0.04 & 0.04 & - & - \\
\hline \multirow{4}{*}{ Meat color $^{\mathrm{T}}$} & Cow & $4.39^{\mathrm{b}}$ & $4.33^{\mathrm{b}}$ & $4.30^{\mathrm{b}}$ & $4.22^{b}$ & - & - & 0.09 & 0.9570 \\
\hline & Bull & $5.67^{\mathrm{a}}$ & $4.74^{\mathrm{ab}}$ & $4.72^{\mathrm{a}}$ & $4.82^{\mathrm{a}}$ & $5.06^{\mathrm{a}}$ & $4.91^{\mathrm{a}}$ & 0.04 & 0.0285 \\
\hline & Steer & $4.75^{\mathrm{ab}}$ & $4.88^{\mathrm{a}}$ & $4.81^{\mathrm{a}}$ & $4.79^{\mathrm{a}}$ & $4.57^{\mathrm{b}}$ & $4.67^{\mathrm{b}}$ & 0.03 & 0.0450 \\
\hline & pooled SE & 0.17 & 0.09 & 0.07 & 0.06 & 0.05 & 0.04 & - & - \\
\hline \multirow{4}{*}{ Fat color $^{\mathrm{w}}$} & Cow & $3.93^{\mathrm{a}}$ & $3.75^{\mathrm{a}}$ & $3.78^{\mathrm{a}}$ & $4.22^{\mathrm{a}}$ & - & - & 0.11 & 0.6486 \\
\hline & Bull & $2.67^{\mathrm{b}}$ & $3.16^{\mathrm{b}}$ & $3.07^{\mathrm{b}}$ & $3.12^{\mathrm{b}}$ & $2.96^{\mathrm{a}}$ & $2.98^{\mathrm{a}}$ & 0.04 & 0.4649 \\
\hline & Steer & $3.00^{\mathrm{ab}}$ & $2.69^{\mathrm{C}}$ & $2.68^{\mathrm{C}}$ & $2.67^{\mathrm{C}}$ & $2.67^{\mathrm{b}}$ & $2.64^{\mathrm{b}}$ & 0.03 & 0.8949 \\
\hline & pooled SE & 0.17 & 0.10 & 0.07 & 0.06 & 0.05 & 0.04 & - & - \\
\hline \multirow{4}{*}{ Textures } & Cow & $1.71^{\mathrm{ab}}$ & $1.54^{b}$ & $1.43^{\mathrm{b}}$ & $1.56^{\mathrm{a}}$ & - & - & 0.05 & 0.2496 \\
\hline & Bull & $2.17^{\mathrm{a}}$ & $1.95^{\mathrm{a}}$ & $2.03^{\mathrm{a}}$ & $1.94^{\mathrm{a}}$ & $2.25^{\mathrm{a}}$ & $2.30^{\mathrm{a}}$ & 0.05 & 0.0601 \\
\hline & Steer & $1.50^{\mathrm{b}}$ & $2.06^{\mathrm{a}}$ & $1.78^{\mathrm{a}}$ & $1.97^{\mathrm{a}}$ & $1.96^{\mathrm{a}}$ & $1.52^{\mathrm{b}}$ & 0.04 & 0.0038 \\
\hline & pooled SE & 0.08 & 0.07 & 0.06 & 0.06 & 0.07 & 0.07 & - & - \\
\hline \multirow{4}{*}{ Quality $^{\alpha}$ grade } & Cow & $2.04^{\mathrm{b}}$ & $1.92^{\mathrm{b}}$ & $1.70^{\mathrm{b}}$ & $1.56^{\mathrm{b}}$ & - & - & 0.08 & 0.1955 \\
\hline & Bull & $3.00^{\mathrm{a}}$ & $2.79^{\mathrm{a}}$ & $2.62^{\mathrm{a}}$ & $2.48^{\mathrm{a}}$ & $2.36^{\mathrm{a}}$ & $2.36^{\mathrm{a}}$ & 0.04 & 0.0049 \\
\hline & Steer & $1.75^{\mathrm{b}}$ & $1.75^{\mathrm{b}}$ & $1.57^{\mathrm{b}}$ & $1.51^{b}$ & $1.49^{\mathrm{b}}$ & $1.07^{\mathrm{b}}$ & 0.04 & 0.0005 \\
\hline & pooled SE & 0.13 & 0.10 & 0.08 & 0.07 & 0.07 & 0.07 & - & - \\
\hline
\end{tabular}

육질등급요인에 대한 출하체중 및 성별 조사 결과는 Table 1 과 같다. 근내지방도는 암소, 수 소 및 거세우에 있어서 각각 3.07 4.00, 1.00 1.96 및 $2.75 \sim 4.22$ 분포로써 출하체중이 증가

Table 1. Carcass traits of quality grade components by sex and market weight

\footnotetext{
a,b,c Means with different superscripts in the same column differ significantly $(\mathrm{P}<0.05)$.

${ }^{\psi}$ Marbling score $(1=$ Lowest, $7=$ highest $) .{ }^{\mathrm{T}}$ Lean $\operatorname{color}(1=$ brightly cherry red, $7=$ extremely dark red.).

${ }^{\mathrm{w}}$ Fat $\operatorname{color}\left(1=\right.$ white, $7=$ dark yello.. ${ }^{\mathrm{s}}$ Texture $: 1=$ very fine, $3=$ very coarse. $)$.

${ }^{\mathrm{y}}$ Maturity $(1=$ under-ossified, $3=$ over-ossified. $)$. ${ }^{\alpha}$ Quality grade $(1$ grade $=$ highest, 3 grade $=$ lowest $)$.
} 
되면서 높아지는 경향을 나타내었으며 $575 \mathrm{~kg}$ 이 하 출하체중 대에서는 암소, 거세우 및 수소 순이었다 $(\mathrm{P}<0.05)$. 성숙도는 $1.00 \sim 2.02$ 의 분포 로써 출하체중이 증가할수록 높았으며 성별로 는 수소 및 거세우가 암소에 비하여 낮았다. 암소의 성숙도가 높은 $(\mathrm{P}<0.05)$ 것은 경산우 비 육에 의하여 뼈의 골화가 진행되었기 때문인 것으로 생각된다.

육색은 암소 및 거세우가 다소 밝은 것으로 나타난 결과는 근내지방도 차에 의한 것으로 사료되며(Table 2, Table 6) 지방색은 동일 체중 대에서 암소가 가장 높았다. 육질등급은 출하 체중이 증가될수록 1 등급 비율이 높은 것으로 나타났으며 성별로는 암소와 거세우가 수소보 다 높은 것으로 나타났다 $(\mathrm{P}<0.05)$. 육질등급 요인별 성간 출하체중간 분산분석 및 상관관계 (Table 2 및 3)를 보면 근내방도, 성숙도, 육색, 지방색, 조직감에는 성간에 차이가 있었고 $(\mathrm{P}<$ $0.01)$, 출하체중은 근내지방도 및 성숙도에 영 향을 주는 것으로 $(\mathrm{P}<0.01)$ 분석되었으며, 육질 등급은 근내지방도 $\left(\mathrm{r}=0.81^{* *}\right)$, 육색 $\left(\mathrm{r}=0.21^{* *}\right)$ 및
조직감 $\left(\mathrm{r}=0.41^{* *}\right)$ 과 상관관계가 높으나 성숙도 와는 상관도가 낮은 결과는 암소 경산우 비육 의 영향인 것으로 생각된다.

이와 같은 시험결과는 Dikeman 등(1998) 및 Park 등(2002)이 출하체중이 높은 비육우일수록 육질등급이 높았다는 보고 및 Mckenna 등 (2002)이 출하체중이 높을수록 근내지방도는 유 의적으로 높았으나 $(\mathrm{P}<0.05)$, 성숙도에서는 차 이가 없다는 결과와 유사한 결과였으며, Park 등(2002)이 근내지방도는 육질등급과 0.81의 상 관관계가 있었다는 보고와 일치하고 있다. 출 하체중 $625 \mathrm{~kg}$ 이상에서 수소의 육색이 거세우 보다 짙은 것으로 분석된 결과는 Seideman 등 (1982)의 보고와 일치하고 있다.

\section{2. 육질등급별 일반성분 및 관능특성}

한우 배최장근의 화학성분 분석결과 및 관능 특성은 Table 4에 나타나 있다. 단백질 함량은 육질등급이 3 등급에서 $1^{+}$등급으로 높아질수록 $21.4 \%$ 에서 $19.18 \%$ 로, 수분함량은 $72.16 \%$ 에서

Table 2. Sum of mean square for carcass qualtiy grading components

\begin{tabular}{|c|c|c|c|c|c|c|}
\hline \multirow{2}{*}{ Source } & \multirow{2}{*}{$\mathrm{df}$} & \multicolumn{5}{|c|}{ Quality grade components } \\
\hline & & Marbling score & Texture & Meat color & Maturity & Fat color \\
\hline Sex & 2 & $282.48 * *$ & $13.12 * *$ & $10.98 * *$ & $13.65^{* *}$ & $37.65^{* *}$ \\
\hline Weight class & 5 & $11.78^{* *}$ & 0.72 & 0.50 & $7.82 * *$ & 0.11 \\
\hline Sex $\times$ weight class & 7 & $82.90 * *$ & $4.93 * *$ & $3.49 * *$ & $7.91^{* *}$ & $14.90 * *$ \\
\hline Error & 772 & 2.00 & 0.63 & 0.49 & 0.30 & 0.41 \\
\hline $\mathrm{R}^{2}$ & - & 0.27 & 0.06 & 0.06 & 0.18 & 0.24 \\
\hline
\end{tabular}

** $\mathrm{P}<0.01$.

Table 3. Simple correlation coefficients between carcass quality grading components

\begin{tabular}{lcccccc}
\hline & 1 & 2 & 3 & 4 & 5 & 6 \\
\hline \hline 1 Marbling score & - & -0.05 & $-0.13^{* *}$ & $-0.37^{* *}$ & $0.08^{*}$ & $-0.81^{* *}$ \\
2 Meat color & & - & -0.02 & $0.21^{* *}$ & $0.19^{* *}$ & $0.21^{* *}$ \\
3 Fat color & & & - & $-0.04^{* *}$ & $0.17^{* *}$ & $0.10^{* *}$ \\
4. Texture score & & & - & $0.21^{* *}$ & $0.41^{* *}$ \\
5. Maturity score & & & & & - & 0.00 \\
6. Quality grade $^{\mathrm{a}}$ & & & & & & - \\
\hline
\end{tabular}

${ }^{*} \mathrm{P}<0.05,{ }^{* *} \mathrm{P}<0.01,{ }^{\text {a }}$ Quality grade $: 1+$ grade $=0 ; 3$ grade $=3$. 
$64.37 \%$ 로, 회분함량은 $0.95 \%$ 에서 $0.85 \%$ 로 감소 $(\mathrm{P}<0.01)$ 하였으며 지방함량은 4.05 에서 $15.24 \%$ 로 증가되었다 $(\mathrm{P}<0.01)$.

평균 단백질함량이 20.68\%인 결과는 Browning 등(1990)이 유럽종에서 $21.43 \%$ 였다는 보고 및 Konishi 등(1995)이 흑모 화우종의 $20.4 \%$ 수준 과 비슷한 수준이었다. 한우 배최장근의 평균 지방함량이 $8.05 \%$ 로 분석된 결과는 Konishi 등 (1995)의 화우거세우의 평균 $11.9 \%$ 수준보다 낮았으며 Miller 등(1995)이 보고한 유럽종 교잡 종의 $5.91 \%$ 수준보다는 높은 결과였고, 한우 $1^{+}$ 등급의 지방함량이 $15.24 \%$ 인 결과는 Ozawa 등 (2000)이 보고한 흑모 화우의 지방함량 $21.1 \%$ 에 비하여 낮은 수준이었다. 평균 수분함량은 69.34\%로써 Van Koevering 등(1995)과 Corah 등 (1995)이 보고한 $72 \%$ 및 75\%에 비해서는 낮 은 결과였으나, 한우에 대하여 Kim과 Lee(2003) 가 보고한 단백질, 수분함량 및 지방함량이 각 각 $19.77 \%, 67.75 \%$ 및 $9.87 \%$ 라는 결과에 비하 여 단백질 및 수분함량은 비슷한 수준이었으며 지방함량은 높게 분석되었다.

쇠고기의 회분함량은 일반적으로 $1 \%$ 이내의 수준으로 알려져 있으나 Miller 등(1988)이 육질 등급별로 큰 차이가 없었다는 보고와 유사한 결과였다.

관능특성을 각 요인별 6점 만점으로 분석한 결과는 Table 4에 분석된 바와 같이 육질등급 이 증가됨에 따라 연도는 $3.19 \sim 4.48$ 로 향미는 4.18에서 4.74로 다즙성은 3.88에서 4.68로 유의
적으로 $(\mathrm{P}<0.01)$ 증가되었다.

이와 같은 결과는 Thompson(2001)이 쇠고기 의 연도변이 중 근내지방도는 가장 중요한 요 인으로써 변이량의 $12 \sim 14 \%$ 점유한다는 보고 와 Shackelford 등(1995)이 연도는 육질등급이 높을수록 우수하였다는 결과가 이를 뒷받침 해 주고 있다. 또한, Lorenzen 등(2003)은 육질등 급이 low select에서 top choice로 증가할수록 향 미 및 다즙성이 각각 0.3 및 0.4 점 증가하였다 는 결과 및 Mckenna 등(2004)이 종합적인 관능 평가 점수는 육질등급에 따라 유의적으로 증가 한다는 보고와 유사한 결과였다.

지방함량이 다즙성 $\left(r=0.46^{* *}\right)$, 연도 $\left(r=0.49^{* *}\right)$ 및 향미 $\left(\mathrm{r}=0.34^{* *}\right)$ 와 높은 상관관계가 있는 것 으로 분석된 결과(Table 6)는 Shackelford 등 (1995)이 근내지방 함량이 높을수록 다즙성 및 연도가 증가된다는 결과와 유사한 결과였다.

\section{3. 육질등급별 물리적 특성}

육질등급에 따른 한우 배최장근의 전단력은 $3.67 \sim 6.41 \mathrm{~kg} / \mathrm{cm}^{2}$ 의 분포로 평균 $5.2 \mathrm{~kg} / \mathrm{cm}^{2}$ 이었으 며 보수력은 $46.31 \sim 49.90 \%$ 의 분포로 평균 $47.39 \%$ 이었고 가열감량은 $24.97 \sim 30.41 \%$ 의 분 포로 평균 $29.4 \%$ 로써 육질등급이 증가할수록 전단력과 가열감량은 감소하였으나 $(\mathrm{P}<0.01)$, 보수력은 차이가 없었다(Table 5).

이와 같은 결과는 May 등(1992)이 Angus종 과 Hereford 종에서 체중증가에 따라 5.06

Table 4. Effect of quality grades on chemical and sensory traits for M. longissimus dorsi

\begin{tabular}{|c|c|c|c|c|c|c|c|c|}
\hline \multirow{2}{*}{ Traits } & \multirow{2}{*}{$\begin{array}{l}\text { No. of } \\
\text { sample }\end{array}$} & \multicolumn{4}{|c|}{ Quality Grade } & \multirow{2}{*}{$\begin{array}{c}\text { Overall } \\
\text { mean }\end{array}$} & \multirow{2}{*}{$\begin{array}{l}\text { Pooled } \\
\text { SE }\end{array}$} & \multirow{2}{*}{$\mathrm{P} \leqq$} \\
\hline & & $1+$ & 1 & 2 & 3 & & & \\
\hline $\begin{array}{l}\text { Protein (\%) } \\
\end{array}$ & 135 & $19.18^{\mathrm{d}}$ & $20.02^{\mathrm{C}}$ & $20.93^{\mathrm{b}}$ & $21.40^{\mathrm{a}}$ & 20.68 & 0.09 & 0.0001 \\
\hline Fat (\%) & 290 & $15.24^{\mathrm{a}}$ & $11.08^{\mathrm{b}}$ & $7.00^{\mathrm{c}}$ & $4.05^{\mathrm{d}}$ & 8.05 & 0.27 & 0.0001 \\
\hline Moisture (\%) & 281 & $64.37^{\mathrm{d}}$ & $67.67^{\mathrm{c}}$ & $69.82^{\mathrm{b}}$ & $72.16^{\mathrm{a}}$ & 69.34 & 0.20 & 0.0001 \\
\hline Ash (\%) & 227 & $0.85^{\mathrm{c}}$ & $0.89^{\mathrm{b}}$ & $0.94^{\mathrm{a}}$ & $0.95^{\mathrm{a}}$ & 0.92 & 0.01 & 0.0001 \\
\hline Tenderness $^{T}$ & 546 & $4.48^{\mathrm{a}}$ & $4.01^{\mathrm{b}}$ & $3.65^{\mathrm{c}}$ & $3.19^{d}$ & 3.67 & 0.04 & 0.0001 \\
\hline Flavor $^{\mathrm{T}}$ & 546 & $4.74^{\mathrm{a}}$ & $4.56^{\mathrm{b}}$ & $4.36^{\mathrm{c}}$ & $4.18^{\mathrm{d}}$ & 4.38 & 0.02 & 0.0001 \\
\hline Juiciness $^{\mathrm{T}}$ & 546 & $4.68^{\mathrm{a}}$ & $4.48^{\mathrm{b}}$ & $4.17^{\mathrm{C}}$ & $3.88^{\mathrm{d}}$ & 4.20 & 0.02 & 0.0001 \\
\hline
\end{tabular}

a,b,c Means with different superscripts in the same row differ significantly $(\mathrm{P}<0.05)$.

${ }^{\mathrm{T}}$ Panel scores were evaluated with a 6 -point scale $(1=$ extremely bad, $6=$ extremely good $)$. 
Table 5. Effect of quality grades on the physical traits for M. longissimus dorsi

\begin{tabular}{|c|c|c|c|c|c|c|c|c|}
\hline \multirow{2}{*}{ Traits } & \multirow{2}{*}{$\begin{array}{l}\text { No. of } \\
\text { sample }\end{array}$} & \multicolumn{4}{|c|}{ Quality Grade } & \multirow{2}{*}{$\begin{array}{c}\text { Overall } \\
\text { mean }\end{array}$} & \multirow{2}{*}{$\begin{array}{c}\text { Pooled } \\
\text { SE }\end{array}$} & \multirow{2}{*}{$\mathrm{P} \leqq$} \\
\hline & & $1+$ & 1 & 2 & 3 & & & \\
\hline WBS $\left(\mathrm{kg} / \mathrm{cm}^{2}\right)$ & 567 & $3.67^{d}$ & $4.31^{c}$ & $5.27^{\mathrm{b}}$ & $6.41^{\mathrm{a}}$ & 5.20 & 0.08 & 0.0001 \\
\hline WHC (\%) & 567 & $49.90^{\mathrm{a}}$ & $47.53^{\mathrm{ab}}$ & $46.31^{\mathrm{b}}$ & $48.09^{\mathrm{ab}}$ & 47.39 & 0.41 & 0.0734 \\
\hline CL (\%) & 567 & $24.97^{\mathrm{b}}$ & $29.53^{\mathrm{a}}$ & $29.62^{\mathrm{a}}$ & $30.41^{\mathrm{a}}$ & 29.40 & 0.25 & 0.0001 \\
\hline Marbling score & 773 & $5.88^{\mathrm{a}}$ & $3.54^{\mathrm{b}}$ & $1.97^{\mathrm{C}}$ & $1.02^{\mathrm{d}}$ & 2.43 & 0.06 & 0.0001 \\
\hline Meat color & 773 & $4.61^{\mathrm{b}}$ & $4.56^{\mathrm{b}}$ & $4.73^{\mathrm{b}}$ & $4.99^{\mathrm{a}}$ & 4.75 & 0.03 & 0.0001 \\
\hline Fat color & 773 & $2.71^{\mathrm{b}}$ & $2.86^{\mathrm{ab}}$ & $2.95^{\mathrm{a}}$ & $2.99^{\mathrm{a}}$ & 2.92 & 0.03 & 0.0436 \\
\hline CIE L* & 560 & $39.13^{\mathrm{a}}$ & $35.80^{\mathrm{b}}$ & $34.71^{\mathrm{bc}}$ & $33.89^{c}$ & 35.14 & 0.22 & 0.0001 \\
\hline$a^{*}$ & 560 & $20.69^{\mathrm{a}}$ & $19.03^{\mathrm{b}}$ & $18.49^{\mathrm{b}}$ & $16.82^{\mathrm{C}}$ & 18.37 & 0.15 & 0.0001 \\
\hline $\mathrm{b}^{*}$ & 560 & $9.23^{\mathrm{a}}$ & $7.74^{\mathrm{b}}$ & $7.21^{\mathrm{b}}$ & $6.55^{\mathrm{c}}$ & 7.34 & 0.10 & 0.0001 \\
\hline
\end{tabular}

a,b,c Means with different superscripts in the same row differ significantly $(\mathrm{P}<0.05)$.

WBS : Warner-Bratzler shear force, WHC : Water holding capacity.

CL : Cooking loss

$5.38 \mathrm{~kg} / \mathrm{cm}^{2}$ 수준과 비슷하였으나 Konishi 등 (1995)이 보고한 흑모화우의 전단력 $5.6 \mathrm{~kg} / \mathrm{cm}^{2}$ 보다는 낮았으며 Thompson(2001)과 Dikeman (1987)이 제시한 전단력 기준치 $4.32 \mathrm{~kg} / \mathrm{cm}^{2}$ 및 $4.54 \mathrm{~kg} / \mathrm{cm}^{2}$ 에 비하여 한우 $2 \sim 3$ 등급육의 전단력 이 $5.27 \sim 6.41 \mathrm{~kg} / \mathrm{cm}^{2}$ 수준으로 높은 것은 한우 고기는 Angus 및 Hereford 에 비하여 연도가 나쁜 것으로 사료되는 바, Jones 등(1990)이 연 도증진을 위하여 제시한 냉각 및 숙성 등에 대 한 체계적인 연구가 필요한 것으로 생각된다.

한우고기의 보수력은 Cross 등(1986)이 보고 한 $39.0 \sim 43 \%$ 보다는 높은 수준이었으나 $\mathrm{Kim}$
과 Lee(2003)가 한우고기의 육질등급이 3등급에 서 1등급으로 증가됨에 따라 보수력은 51.3 55.6으로 증가된다는 보고와 비슷한 결과였으 며 가열감량은 Van Koevering 등(1995)이 보고 한 $21.7 \sim 31.7 \%$ 의 수준 및 Konishi 등(1995)이 보고한 American 흑모 화우의 $29.2 \%$ 과는 비슷 한 수준이었다.

전단력은 다즙성, 연도 및 향미와 각각 $-0.45^{* *}$, $-0.62^{* *}$ 및 $-0.38^{* *}$ 의 부의 상관관계가 있는 것 으로 분석된 결과(Table 6)는 May 등(1992) 및 Park 등(2002)의 결과와도 일치하고 있다.

배최장근의 육색을 명도 $\left(\mathrm{L}^{*}\right)$, 적색도 $\left(\mathrm{a}^{*}\right)$, 황색

Table 6. Simple correlation coefficients among meat quality and measurements

\begin{tabular}{|c|c|c|c|c|c|c|c|c|c|c|c|}
\hline & Protein & Fat & Ash & Moisture & WBS & WHC & $\begin{array}{c}\text { Juici- } \\
\text { ness }\end{array}$ & $\begin{array}{c}\text { Tender- } \\
\text { ness }\end{array}$ & Flavor & $\begin{array}{l}\text { Color } \\
\text { (L) }\end{array}$ & MS \\
\hline Protein & - & $-0.85^{* *}$ & $0.54^{* *}$ & $0.79 * *$ & $0.38 * *$ & 0.13 & $-0.28 * *$ & $-0.34^{* *}$ & $-0.26 * *$ & $-0.35^{* *}$ & $-0.68^{* *}$ \\
\hline Fat & & - & $-0.60 * *$ & $-0.95^{* *}$ & $-0.56^{* *}$ & $0.18^{* *}$ & $0.46^{* *}$ & $0.49 * *$ & $0.34^{* *}$ & $0.18^{* *}$ & $0.78^{* *}$ \\
\hline Ash & & & - & $0.52 * *$ & $0.32 * *$ & -0.10 & $-0.34^{* *}$ & $-0.28 * *$ & $-0.33 * *$ & $-0.20 * *$ & $-0.41^{* *}$ \\
\hline Moisture & & & & - & $0.52 * *$ & -0.11 & $-0.38 * *$ & $-0.47 * *$ & $-0.30 * *$ & $-0.13^{*}$ & $-0.73^{* *}$ \\
\hline WBS & & & & & - & -0.03 & $-0.45^{* *}$ & $-0.62 * *$ & $-0.38 * *$ & $-0.25^{* *}$ & $-0.41^{* *}$ \\
\hline WHC & & & & & & - & 0.08 & 0.07 & $0.10^{* *}$ & $0.16^{* *}$ & $0.14^{* *}$ \\
\hline Juiciness & & & & & & & - & $0.71^{* *}$ & $0.67 * *$ & $0.12^{* *}$ & $0.41^{* *}$ \\
\hline Tenderness & & & & & & & & - & $0.63 * *$ & $0.16^{* *}$ & $0.43^{* *}$ \\
\hline Flavor & & & & & & & & & - & $0.16^{* *}$ & $0.36^{* *}$ \\
\hline CIE L* & & & & & & & & & & - & $0.39 * *$ \\
\hline MS & & & & & & & & & & & - \\
\hline
\end{tabular}


도 $\left(\mathrm{b}^{*}\right)$ 로 분석한 결과 육질등급이 3 등급에서 $1^{+}$ 등급으로 증가할수록 $\mathrm{CIE} \mathrm{L}, \mathrm{a}^{*}, \mathrm{~b}^{*}$ 값은 증가되 는 경향이었다 $(\mathrm{P}<0.01)$. 표준색도판에 의해 분 석된 육색은 4.61 4.99의 분포를 나타내었고, 지방색은 $2.71 \sim 2.99$ 의 분포를 나타내었으며 육 질등급이 높을수록 낮은 수준을 나타내었다.

한우고기의 육색은 Ozawa 등(2000)이 흑모 화우의 명도, 적색도, 황색도 값이 각각 45.2, 22.2, 15.7 이었다는 결과보다는 낮은 경향 치 를 보이고 있다.

$$
\text { IV 요 약 }
$$

1995년부터 10년간 축산연구소에서 도축된 한우도체 773두에 대하여 한우도체의 육질등급 판정 요인특성을 출하체중 및 성에 따라 분석 하였으며 육질등급에 따른 배최장근의 이화학 적 특성 및 관능특성을 조사하였다.

육질등급은 출하체중대별로 거세우 및 암소 가 수소에 비하여 우수하였으며 $(\mathrm{P}<0.05)$ 출하 체중이 높을수록 육질등급이 향상되었다.

육질등급 판정요인 중 근내지방도, 조직감, 성숙도, 육색 및 지방색은 성별로 차이가 $(\mathrm{P}<$ $0.01)$ 있었으나 출하체중별로는 근내지방도와 성숙도 요인만 차이가 있는 것으로 분석되었다. 한우의 최종 육질등급은 근내지방도 $\left(\mathrm{r}=-0.81^{* *}\right)$, 육색 $\left(\mathrm{r}=0.21^{* *}\right)$, 지방색 $\left(\mathrm{r}=0.10^{* *}\right)$ 및 조직감 $(\mathrm{r}=$ $0.41^{* *}$ )과 상관관계가 있었으나 성숙도는 영향 이 없었다.

배최장근에서 측정한 평균 단백질함량, 수분 함량 및 지방함량은 각각 $20.68 \%, 69.34 \%$ 및 $8.05 \%$ 로 육질등급이 3 등급에서 $1^{+}$등급으로 우 수할수록 단백질함량 및 수분함량은 감소되었 고 지방함량은 증가되었다 $(\mathrm{P}<0.01)$. 전단력, 가 열감량 및 보수성은 평균 $5.2 \mathrm{~kg} / \mathrm{cm}^{2}, 129.4 \%$ 및 $47.3 \%$ 로서 육질등급이 증가됨에 따라 전단력과 가열감량은 감소되었으나 $(\mathrm{P}<0.01)$, 보수력은 유의적인 차이가 없었다.

육색은 육질등급이 증가함에 따라 명도와 적 색도 및 황색도는 유의적으로 증가하였다 $(\mathrm{P}<$ 0.01). 관능특성에서, 풍미와 다즙성은 및 연도 는 육질등급이 우수할수록 유의적으로 증가하
였다 $(\mathrm{P}<0.01)$.

배최장근의 지방함량은 전단력 $\left(\mathrm{r}=0.56^{*}\right)$ 과 보 수성 $\left(\mathrm{r}=0.18^{* *}\right)$ 및 다즙성 $\left(\mathrm{r}=0.46^{* *}\right)$, 연도 $(\mathrm{r}=$ $\left.0.49^{* *}\right)$, 향미 $\left(\mathrm{r}=0.34^{*}\right)$ 에 상관관계가 높은 것으 로 분석되었으며 전단력이 높을수록 관능특성 요인인 향미, 연도, 다즙성이 나쁜 것으로 분석 되었다.

\section{$\mathrm{V}$ 인 용 문 헌}

1. AOAC. 1995. Official methods of analysis. Arlington, VA: Association of Official Analytical Chemists.

2. Barker, B. P., Mies, W. L., Turner, J. W., Lunt, D. K. and Smith, S. B. 1995 . Influence of production system on carcass characteristics of $\mathrm{F} 1$ Wagyu $\times$ Angus steers and heifers. Meat Sci. 41:1-5.

3. Browning, M. A., Huffman, D. L., Egbert, W. R. and Jungst. S. B. 1990. Physical and compositional characteristics of beef carcasses selected for leanness. J. Food Sci. 55:9-14.

4. Corah, T. J., Tatum, J. D., Morgan, J. B., Mortimer, R. G. and Smith, G. C. 1995. Effect of a dexamethasone implant on deposition of intermuscular fat in genetically identical cattle. J. Anim. Sci. 73:3310-3316.

5. Cross, H. R., Savell, J. W. and Francis, J. J. 1986. National consumer retail beef study. Proc. Recip. Meat Conf. 39:112-113.

6. Dikeman, M. E., Cundiff, L. W., Gregory, K. E., Kemp, K. E. and Koch, R. M. 1998. Relative contributions of subcutaneous and intermuscular fat to yields and predictability of retail product, fat trim and bone in beef carcases. J. Anim. Sci. 76:16041612.

7. Dikeman, M. E. 1987. Fat reduction in animals and the effects on palatability and consumer acceptability. Proceed. 40th Recip Meat Cof, USA, pp. 93-107.

8. Donald, L. M. and Merkel, R. A. 1993, Live animal carcass evaluation and selection manual. Hunt. Pablishing Company. 129-130.

9. Jeremiah, L. E., Dugan, M. E. R., Aalhus, J. L. and Gibson, L. L. 2003. Assessment of the relationship between chemical components and palatability of major beef muscles and muscle groups. Meat Sci. 65:1013-1019.

10. Jones,. D. K., Savell, J. W. and Cross, H. R. 1990. The influence of sex-class, USDA yield 
grade and USDA quality grade on seam fat trim from the primals of beef carcasses. J. Anim. Sci. 68:1987-1991.

11. Kim C. J. and Lee, E. S. 2003. Effects of quality grade on the chemical, physical and sensory characteristics of Hanwoo(Korean native cattle) beef. Meat Sci. 63:397-405.

12. Konishi, K., Nade, T., Maeda, M. and Uchiyama, M. 1995. Determination of fat content in beef loin by image analysis system. Anim. Sci. Technol. (Jpn.) 66:548-554.

13. Lorenzen, C .L., Miller, R. K., Taylor, J. F., Neely, T. R., Tatum, J .D., Wise, J. W., Buyck, M. J., Reagan, J. O. and Savell, J. W. 2003. Beef Customer Satisfaction: Trained sensory panel ratings and Warner-Bratzler shear force values. J. Anim. Sci. 81:143-149.

14. May, S. G., Dolezal, H. G., Gill, D. R., Ray, F. K. and Buchanan, D. S. 1992. Effects of days, fed, carcass grade traits and subcutaneous fat removal on postmortem muscle characteristics and beef palatability. J. Anim. Sci. 70:444-453.

15. Mckenna, D. R., Roeber, D. L., Bates, P. K., Schmidt, T. B., Hale, D. S., Griffin, D. B., Savell, J. W., Brooks, J. C., Morgan, J. B., Montgomery, T, H., Belk, K. E. and Smith, G. C. 2002. J. Anim. Sci. 80:1212-1222.

16. Mckenna, D. R., Lorenzen, C. L., Pollok, K. D., Morgan, W .W., Mies, W. L., Harris, J. J., Murphy, R., McAdams, M., Hale, D. S. and Savell, J. W. 2004. Interrelationships of breed type, USDA quality grade, cooking method, and degree of doneness on consumer evaluations of beef in Dallas and San Antonio, Texas, USA. Meat Sci. 66:399-406.

17. Miller, M. F., Ramsey, C. B., Claborn, S. W. and Wu, C. K. 1995. Effects of breed type and accelerated fat removal on subprimal yields and carcass values. J. Anim. Sci. 73:1055-1063.

18. Miller, M. F., Cross, H. R., Baker, J. F., Byers, F. M. and Recio, H. A. 1988. Evaluation of live and carcass techniques for predicting beef carcass composition. Meat Sci. 23:111-129.
19. Miller, M. F., Carr, M. A., Ramsey, C. B., Crockett, K .L. and Hoover, L. C. 2001. Consumer thresholds for establishing the value of beef tenderness. J. Anim. Sci. 79:3062-3068.

20. Ozawa, S., Mitsuhashi, T., Mistsumoto, M., Matsumoto, S. Itoh, N., Itagaki, K., Kohno, Y. and Dohgo, T. 2000. The characteristics of muscle fiber types of longissiums thoracis muscle and their influences on the quantity and quality of meat from Japanese Black steers. Meat Sci. 54:65-70.

21. Park, G. B., Moon, S. S., Ko, Y. D., Ha, J. K., Lee, J. G., Chang, H. H. and Joo, S. T. 2002. Influence of slaughter weight and sex on yield and quality grades of Hanwoo(Korean native cattle) carcasses. J. Anim. Sci. 80:129-136.

22. Ryoichi, S., Degychi, T. and Nagata, Y. 1993. Effectiveness of the filter paper press method for determining the water holding capacity of meat. Fleischwirtsch 73:1399-1400.

23. SAS.1996. SAS/STAT user's guide

24. Serra, X., Gil, M., Gispert, M., Guerrero, L., Oliver, M. A., Sanudo, C., Campo, M. M., Panea, B., Olleta, J. L., Quintanilla, R. and Piedrafita, J. 2004. Meat Sci. 66:425-436.

25. Shackelford, S. D., Wheeler, T. L. and Koohmarmie, M. 1995. Relationship between shear force and trained sensory panel tenderness ratings of 10 major muscles form bos indicus and bos taurus cattle. J. Anim. Sci. 73:3333-3340.

26. Seideman, S. C., Cross, H. R., Oltjen R. R. and Schanbacher, B. D. 1982. Utilization of the intact male for red meat production. A review. J. Anim. Sci. 55:826-840.

27. Thompson, J. M. 2001. The relationship between marbling and sensory traits. Marbling symposium. Coffs Harbour, Australia. pp. 77-87.

28. Van Koevering, M. T., Gill, D. R., Owens, F. N., Dolezal, H. G. and Strasia, C. A. 1995. Effect of time on feed on performance of feedlot steers, across characteristics, and tenderness and composition of longissimus muscles. J. Anim. Sci. 73:2128.

(접수일자 : 2004. 7. 27./ 채택일자 : 2004. 10. 21.) 